\section{親子の地域環境学習プログラム の開発に関する考察 一学習型環境デザインワークショップの 実践と課題一}

\title{
PROGRAM DEVELOPMENT FOR LEARNING THE COMMUNITY ENVIRONMENT WITH CHILDREN AND PARENTS \\ - Consideration from practice of workshop for learning-
}

\section{鈴木賢—— - 1 小松 尚 — $* 2$ \\ 中井孝幸 - $*$ 3}

キーワード :

環境学習, ワークショップ, 環境デザイン, 親子, 学習プログラム

Keywords :

Learning of environment, Workshop, Environmental design, Children and parents, Learning program

\author{
Ken-ichi SUZUKI $-* 1$ \\ Takayuki NAKAI - *3
}

This paper reports the practical study on program development for learning the community environment, through the workshops for two years. This program consists of three phases: motivating, learning, and designing. Twenty children and parents participated in this program with voluntary staffs, and experienced investigation of community and design of architecture and urban design. It is resulted that it is important to take into consideration of the followings as well as methods for learning community environment: enhancement of communications among participants, relationship of children to their parents, continuity and conclusiveness of programs, skill for conveying the professional knowledge plainly.

\section{1. 目的と方法}

住民が自ら生活する地域環境に対し，問題意識をもって主体的に 関わることのできる資質を持つことは重要である。しかし，急速な 都市化現象に伴い，住民と地域固有の文化・歴史・自然環境との接 点が減少し，家族や近隣住民との関係も薄らいでいる。しかも住民 自身が生活環境の構築や維持に直接関与する術と機会を得ていない のか現状である。生活環境とそこで展開される住民生活そのものと の北離は，住民の地域環境への無関心をより助長する。地域に無関 心な大人以上に，成長期の子どもたちにとって，地域環境での実体 験か浠薄であることの影響は大きい。

子どもにとって最も身近な大人である親と一緒に，身近な環境に 関する共通話題をもつことは，地域環境が生活を支えているという 意識と地域への愛着を育み，他人へ目を向けさせる第 1 歩であろう。 親にとっても子どもの学習活動を通じて, 地域を再認識出来る良い 機会である。こうした地域環境に関心を寄せる動機付けに対して， 建築や都市に関わる専門家がより良いきっかけを提供することは， 有効な方法の一つである。

筆者らは，子どもとその親を対象とした地域環境学習のためのプ ログラムを作成し, 1998 年から 2 年間, ワークショップ (以下W S）の実践を試行してきた。本報告ではこの実践を通じ，地域環境 学習プログラムの成果と有効性, 実施上の課題について整理・報告 し, 現時点での考察を行うこととする。

\section{2. 先行研究, 活動との関係}

ワークショップは, 住民主体のまちづくりや各種建築計画を促進 する手法として各地で採用されつつあり，研究者や実践者によって
その成果や有効性か論じられるようになってきている。

住民や子どもの環境学習という点では，建築学会が毎年「親と子 の建築講座」を開催しているのをはじめ, それぞれの問題意識の元, 全国各地で実施され始めている。同時に，先駆的事例を報告する書 籍や手引き図書iも発刊されている。

環境学習の手法やプログラムに関する研究では, 稲葉がインスタ ントカメラの手法的可能性について事例検証している が子供との体験活動や駅整備を対象にしたWSを通じて，住民の視 点の広がりや新たな価值観の生成等を論じているiv。全般的にはよ うやく議論の端緒につき，実践をふまえた議論が今後重ねられる心゙ き段階と思われる。

\section{3. 環境デザインワークショップの概要}

\section{3-1. 対象と日程}

筆者らからなる企画メンバー・が, 名古屋市千種区内の上野小学 校 (図 1) の $5 \cdot 6$ 年生とその親に，学校を通じて自由意思によ るWSへの参加を持ちかけた。上野小学校を対象にして募った理由 は，小学校区程度が地域学習を行うのに適当な範囲と考えたこと, 地域の特徴や魅力, 問題点を当事者として共感できる親子を求めた こと, WSの内容が小学校教育にも関連性が梁いこと, この学区が 比較的安定した市街地であること，学区内にある大学施設が活用で きたこと等が挙げられる。また作業能力や学校教育による知識レべ ルなどを考えて，5・6年生を対象にした。

WSは 98 年の 8 月からスタートし, 12 月まで月 1 回のペース で小学校が休日となる土曜日や祝日の午後 1 時から 5 時の間に実施 開催した。99 年は前年の反省をふまえ，プログラムの構成は維持

*1 Assoc. Prof., School of Design \& Architecture, Nagoya City Univ., Dr. Eng.

(于464-0083 名古屋市千種区北千種2-1-10)

*2 名古屋大学工学部 講師・博士 (工学)

*3 豆重大学工学部 助手・博士 (工学)
*2 Lecturer, Department of Archi., School of Eng., Nagoya Univ., Dr. Eng.

*3 Research Assoc., Department of Archi., School of Eng., Mie Univ., Dr. Eng. 
しながらも改良を加えて，同時期に 5 回の WS を実施した（表 1）。WSの会場は, 上野小学校区内にある名古屋市立大学芸術工 学部キャンパスである。

\section{3-2. ワークショップへの参加者}

98 年にエントリーした親子は, 小学生 24 名とその親 18 名, 計 42 名である ${ }^{\mathrm{vii}}$ 。99 年には, 小中学生 23 名 (中学生 6 名, 小学生 17 名, また 23 名中 10 名は前年からの継続参加）, 親 9 名（内 5 名が継続参加）のエントリーがあったviii。各年とも5回連続での 参加を前提に募ったが, 都合により何回か参加できなかったり，途 中から参加しなくなった子や親がおり，途中から新規参加の子ども も若干いたが，毎回の能加親子の数はエントリー数より少ない。

親子はWSの企画運営や準備には関与せず，当日の作業に専念し た。そのため，企画メンバーの呼びかけに賛同した設計事務所の若 手所員をはじめとする社会人や，建筑学や教育学を尃攻する大学生 が, 自発的に協力スタッフ（2 年とも約 25 名）としてWS当日の 円滑な実施・運営のために，親子への直接指導や手助けを行った。

\section{3-3. プログラム構成とワークショップの内容}

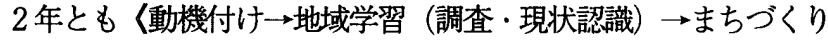
学習 (創作・提案) 〉というプログラム構成で，5回のWSを組み 立てた。また 2 年目は，前年の反省と継続して参加した親子への配 虑をして，内容の改良を行った（表1）。

（1）動機付けプログラム：「建築デザイナーに挑戦」と題し たW Sを開催した。近隣にドーム球場があることから，身近な事例 に関連した題材として，等身大の構造模型の制作を行った。

（2）地域学署プログラム：次に現状認識を深めるために，日 常の行動範囲を確認したり，学区の知らない場所を確認することを 目的とする「ガリバーマップでまち自慢」と題したWSを第 2 回目 に開催した。続く第 3 回WSでは「まちなみ探偵団」として実際に 学区へ出て,フィールドワークを行った。五感を働かせて住みなれ た生活環境を見直してみるという内容である。

（3）まちづくり学習プログラム：以上をふまえ，創作と提案 をしながら，まちづくりを学習するプログラムに入っていった。第 4 回WSは「私の住んでみたい家」と題して，建築やまちを考える 出発点である住宅を取り上げた。住宅の模型づくりを通じて, 創造 の楽しさや生活環境を自ら作ることの重要性を知るのが目的である。 そして第 5 回WSは「まちづくりゲーム」として，これまでに得た 知識をベースに，街区のデザインやまちの紹介マップを制作した。 話し合いながらデザインし，まとめることを重視した内容である。

\section{3-4. 各回のワークショップの内容構成と取り組み方}

各回のWSは，基本的に〈導入作業 $\rightarrow$ 制作・作業 $\rightarrow$ 発表〉という 構成である。親子は基本的に各々制作・作業を行ったが，親子は各 回の内容によって一緒に作業したり，別グループで作業した。また 各回の終了後と各年のWSが終了した時点で，参加親子と協力ス夕 ッフには感想文を書いてもらった。

\section{3-5. ワークショップの内容検討や進行とスタッフの役割}

WSの企画と募集は，2 年とも企画メンバーが行った。 WSの内 容検討や事前準備，当日の進行は，1年目は企画メンバーか担当し

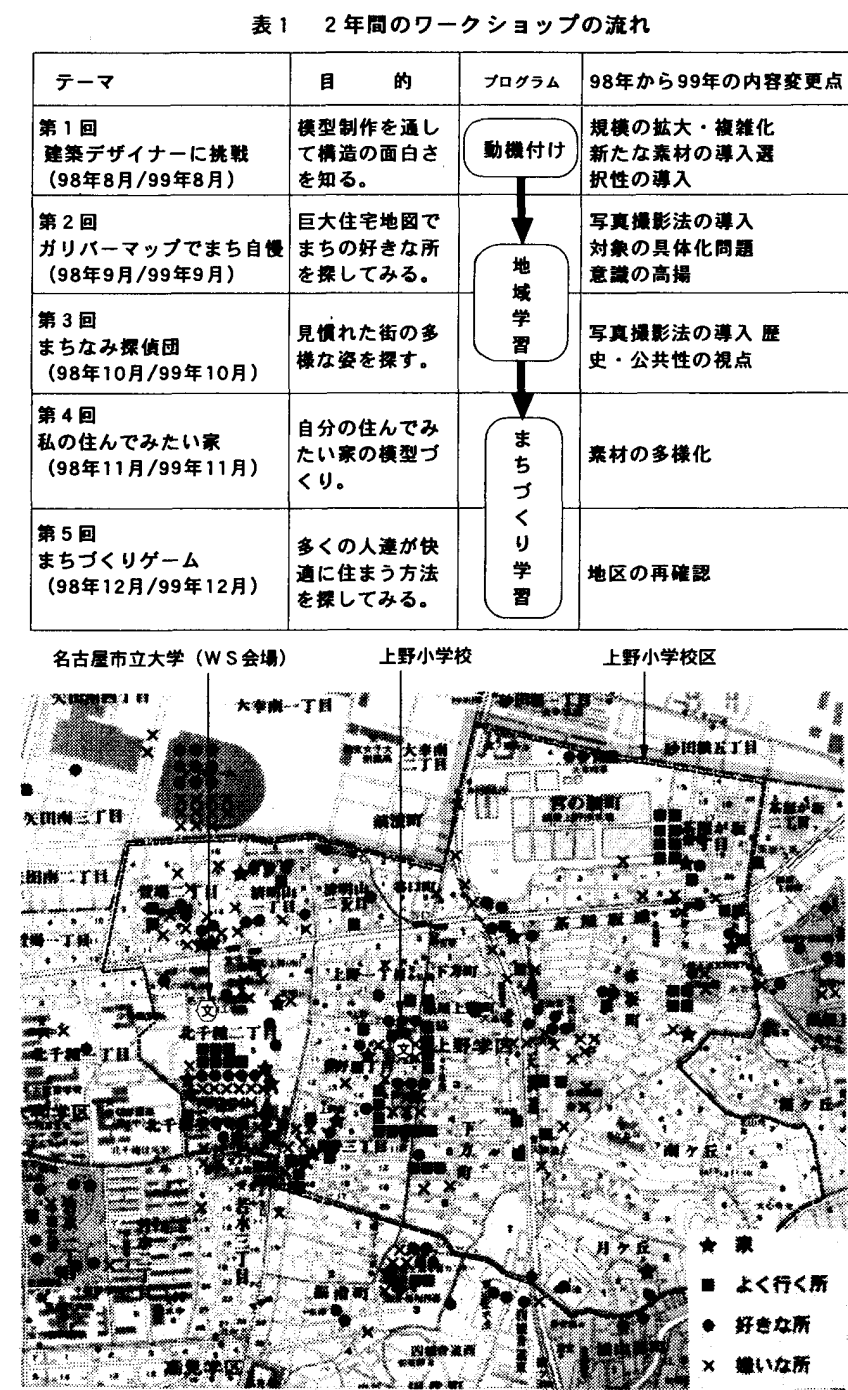

图 1 学区の範囲と巨大地図 [98年第 2 回] 上に貼られたシール

た。2年目を迎える際に，1年目に参加した親と協力スタッフを交 えて，1年目の反省と今後の方針を話し合う機会を持った。そこで あがった要望や 1 年目の感想文における意見・提案を考慮して，企 画メンバーと協力スタッフ数名で 2 年目の内容検討を行った。 2 年 目はその協力スタッフも，事前準備や当日の進行を担当した。

\section{2 年間のW Sの実施内容と結果}

1 年ごとのプログラムを考察対象とし, 各回のWS S 具体的内容 と実施結果, 反省点, 2 年目の改良点, 参加親子の感想等を以下に 整理して述べる。

\section{4-1. 98 年の内容と結果}

(1) [98 年第 1 回］動機付けプログラム

「建築デザイナーに挑戦」：プラスチック段ボールのドーム とレンガのアーチの制作

[小学生 21, 親 18, 協カスタッフ 20 : 計59 名]

制作にはいる前に初対面の親子と企画メンバー，協力スタッフが うち解けあうために，「人間ストラクチャー」という準備体操㐫を 行った。次に，本題である模型制作を行った。

カラー・プラスチック製の段ボールを使った直径 $2 \mathrm{~m}$ の正 60 面 体の半球ドームと, 実際のレンガを用いて直径 $2 \mathrm{~m}$ のアーチを制 作したx。後者は成功せず，再挑戦の期待を残しだが，経験したこ 
とのない大きさの模型づくりに参加できたことの喜びや，この種の 構造物への興味関心か増したこと，共同作業によって参加者同士の 一体感が生まれた，といった感想か渏せられた。一方，親からは， レンガのアーチが失敗したこともあって，構造的な理論説明を敢え て省いたことに対する不満か聞かれた。（写真 1-1）

(2) [98 年第 2 回] 地域学署プログラム(1)

\section{「ガリパーマップでまち自慢」：巨大地図上での街並み探索}

\section{[小学生 19, 親 14, 協力スタッフ 24 : 計57 名]}

ます緊張感をほぐすため, 参加者同士でインタビューゲームを行 い，地域に目を向ける準備として，小学生には家から学校までの認 知地図を，親には自分が通った学校の絵を書いてもらっだ视。

次にW Sの準備作業として，上野学区の住宅地図 (1/1500) を 1/250に拡大コピーしたものを全員で教室の床に広げ, 貼り合せ て，巨大地図（ガリバーマップ：概ね $9 \mathrm{~m} \times 7 \mathrm{~m}$ ）を完成させた。 そして，まず靴を脱いで，学区全体の $1 / 250$ の巨大地図上を歩くと いう印象的体験を行い，次に生活圈を確認するために，自分の家や よく行く友達の家や商店などにシールを貼った。さらに，好きな場 所に緑，嫌いな場所に赤のシールを貼り，サインペンでその理由を 書き込んだ（図 1) xiii。最後に，様々な地域の情報が盛り込まれ た巨大地図の上で，一人一人がまちの自慢話をした。

課題の間や休想時に，地図の上を行ったり来たりして地域を見直 したり，他人のコメントを哯き込む親子の姿が多く見られた。子ど もたちの感想では，巨大地図の出現に対する素直な驚きや，他人が 書き込む内容，子どもだけでなく大人の行動にも興味を示している。 また自分がいかにこの地域を知らないか鷘き, 改めて行動範囲を確 認できることの面白さを述べている。（写真 1-2）

(3) [98 年第 3 回] 地域学習プログラム(2)

\section{「まちなみ探偵団」：五感によるまち探索}

\section{[小学生 15, 親 13, 協力スタッフ 18 : 計 46 名]}

巨大地図による地域の確認に続き, 今回は参加親子を 4つのグル ープに分け，各々与えられた調査エリアについて，音やにおいを探 す, 温度を測定する, 気になる場所をインスタントカメラに収める, 高齢者に地域の歴史をインタビューするという課題を与え, まちに くり出した。調査時間 90 分をもてあますのではないかという企画 メンバーの心配に反し，多くのチームか時間を超過して戻ってきた。

その後, 調査項目について報告発表を行い, 最後に名古屋市域の 表面温度を人工衛星で撮った写真を紹介し，ヒートアイランドの状 況や原因を解説した。

特定の課題をもって探索することで，今まで意識しなかった視点 の存在に気付かされたという感想が多く寄せられた。（写真1-3）

(4) [98 年第 4 回 $]$ まちづくり学習プログラム(1)

\section{「私の住んでみたい家」：限定した材料での住宅模型制作} [小学生 16, 親 12, 協力スタッフ $16:$ 計 44 名]

最初に，世界に見られる様々な住宅のスライドを見た。そしてそ の間に自分の住んでみたい家のテーマを各自設定した。

設定したテーマにしたがって，スチレンボードを主材料に使って 1/50の模型を制作した。具体的な敷地は設定せず，A 3 版（すな わち，ほぼ $15 \mathrm{~m} \times 20 \mathrm{~m} ）$ の中に収まることを条件とした。

スケール感を感じて制作してもらうために，人のミニチュアと 4.5 帖，6帖，8帖相当のブロックをベースに考えるよう誘導した が，後者は逆に思考の制約になってしまった人がいた。しかし協力
スタッフの手助けもあり，最後には光や緑など季節感を題材とする テーマや，空や屋根などの部分にこだわるテーマ，遊具やプールを 取り込んだ作品など，実に多様なテーマの住宅模型が出揃った。

作業のプロセスは様々であったが, 最終的には全員が個性的でユ ニークな住宅模型を完成させている。しかし，住宅模型の制作はほ とんどの親子にとって初めての経験であったため, 各人の作業の立 ち上がりに時間がかかり，制作作業だけに時間を費やさざるを得な かったことか課題である。（写真 1-4）

(5) [98 年第 5 回］まちづくり学署プログラム(2)

「まちづくりゲーム」：住宅模型を並べての街区デザイン [小学生 19, 親 13, 協カスタッフ $15:$ 計 47 名]

第 4 回WSで作った住宅模型を使ってまちづくりゲームを行なう ために，まず住宅の特徵や考えたことを各自発表した。次に親チー ム, 子どもチームに分かれ，小学校に隣接する街区を $1 / 50$ に拡大 した地図上に各々住宅模型を配置し, 街区のイメージを話し合いな がら，協調してまちづくりをした。

作業が先行する子どもチームと, 腕組みして話し合いが先行する 親チームの対比的な行動が印象的であった。最後にモデルスコープ を通したスクリーン映像を見ながら，街区の考え方を各々発表した。 模型材料の色彩や素材を生かしながら，せせらぎや遊歩道等なかな か現実には実現できない外部空間の制作を通じて，外部空間の公共 性やまちの雲囲気を考える時間をもつことができた。（写真 1-5）

\section{4-2. 99 年の内容と結果}

\section{(1) [99 年第 1 回] 動機付けプログラム}

「建築デザイナーに挑戦」：大規模化・複雑化した段ボール のドームとレンガのアーチと, 竹製パオの骨組み制作

[小学生 13, 中学生 5, 親 8, 協力スタッフ 24 : 計50 名]

前年の経験をふまえ，制作する模型を大規模化，複雑化したり， 新たな材料を取り入れた。段ボールのドームは直径を $5 \mathrm{~m}$ とし， よりダイナミックなものとした。レンガのアーチはより高度な制作 にすべく，4つ足のアーチとした。また，新たに割竹を使ったドー ム状のパオの骨組みを制作した。さらに，親子がじっくり制作に取 り組めるよう，いずれか一つを選択させることにした。

年間を通した感想文の中で子どもたちの多くから「この巨大模型 制作の WS が最も楽しい」といった声が多く聞かれた。また「制 作者の一人であり, お客さんではない」という, 主体的参加の必要 性を記した親もいた。動機付けプログラムとして, 頭から理解する よりも，体を動かして関心を引き寄せるこの種の制作の有効性を示 すものといえる。(写真 2-1)

(2) [99 年第 2 回] 地域学習プログラム(1) 「ガリバーマップでまち自慢」：写真撮影法によるまち探索 [小学生 14, 中学生 5, 親 8, 協力スタッフ 24 : 計51 名]

2 年目は地域の特色をより具体的に浮かび上がらせるために，予 め使い捨てカメラを親と子に1台ずつを渡し，「自分の家」「身の 回りの色」「気になる場所」を撮影する宿題を与え，WSの前に必 要となる素材を準備させた。W Sでは撮影された写真をテーマごと のシート (A 4 版) に1枚づつ貼ってコメントを記入し，それを前 年使用した巨大地図上に置いて，まちなみ探索を行った。

「気になる場所」のうち，親か撮った写真にはこの地域のユニー クなもの ${ }^{\mathrm{xN}}$ が多かった。一方, 子どもが撮った写真には教えたい場 


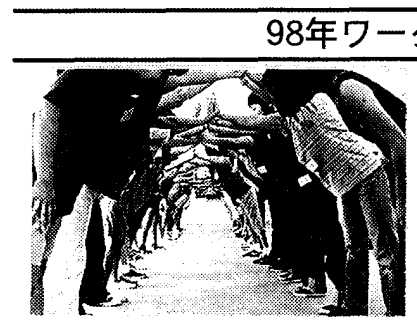

体を使ってアーチやドームの力の流れを 体感してみる人間ストラクチャー。「建 築と子供」からヒントを得て、模型制作 の準碏体操として行った。知らない者同 士が自然に打ち解けることができた。 写真1-1 建築デザイナーに挑戦 (98.08.25)

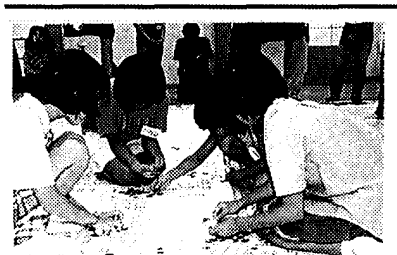

学区の住宅地図を1/250に拡大。 $9 \mathrm{mX}$ 7 mの巨大地図が出現した。さっそくカ リバーになって、よく行く場所や好きな 場所、嫌いな場所にシールを䀡った。人 の行動や考え方がよくわかる。

写真1-2 ガリバーマップでま

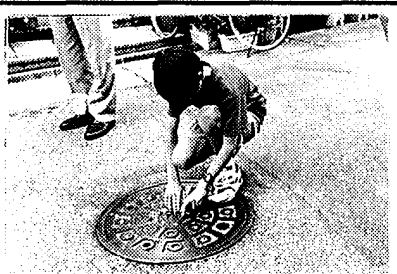

「いろいろな温度を計ろう」という課題 が与えられた。マンホールの温度とアス ファルトの温度、緑陑の温度を比ベてみ る。最後に都市のヒートアイランド現象 の説明を䦚き、課題の意味を知る。 写真 1-3 まちなみ探偵団 (98.10.10)

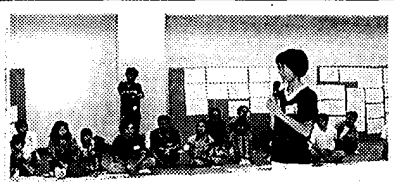

地図のうえで、一人一人が学区の好きな 場所や自慢できる場所を発表しあった。 知っているようで知らないことが披露さ れた。大勢の人の前でリラックスして発 表できる祭围気つくりが重要である。
カラープラスチック製段ボールによる 徍 2 mの正60面体半队球ドームの制作。 はじめはカッターの使い方も危なげだつ たか最後には熟練した。日常作る譏会の ち自慢 (98.09.26)

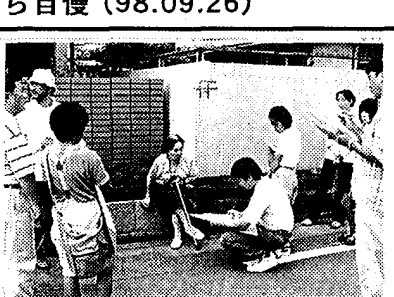

地元のお年寄りに学区の昔のことをイン タビューした。知らないお等寄りに声を かけるのははじめての経験であった。親 も知らない事実を発見したり、世代を超 流のきっかけが生まれた。

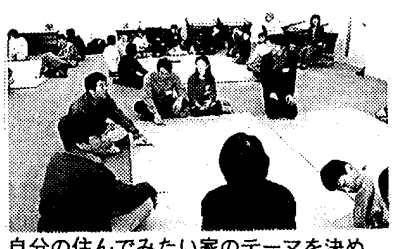

自分の住んでみたい家のデーマを決め、 1/50の模型を作る。部屋周辺には製图

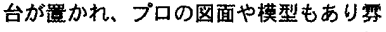
囲気を高めた。考えてから動く親と、ま ずは作り出す子どもとは対照的である。 写真1-4 私の住んでみたい家

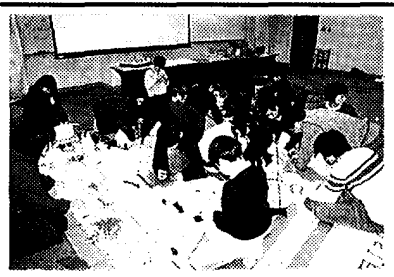

前回作った模型を各自持ち寄り住宅地の 外構デザインを行った。住宅制作では個 人のデザインに没頭できたが、街区では 公共性を問われることになり，近膦関係 者との話し合いを体験した。

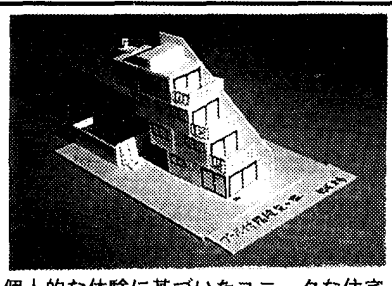

個人的な体験に基づいたユニークな住宅 が50楝ほどできた。器や屋根の形にこた わったりプールや多目的ホールを取り入 クるなど槏々。親子同士で相互の作品を 話題にするのも新鮮である。

(98.11.28)

写真1-5 まちつくりゲーム (98.12.12)

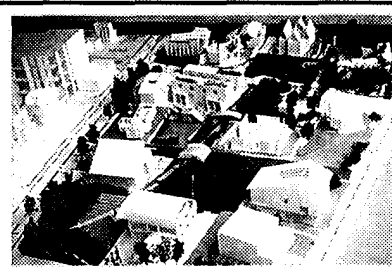

实際の小学校の周辺教地に子どもの住宅地 とおとなの住宅地を作り上げた。おとなに は計画の意図が見え偲れするが、子どもに は無秩序な㡏しさがある。住宅が集合した ときの「硕観」を知るきっかけとなった。

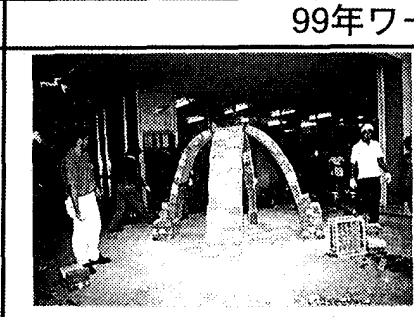

レンガによるアーチの制作。98年には4 基のアーチ全てが崩壊したため、アーチ に再挑戦というプログラムを急耚実施し た。その経験から縣垂線の型枠を使うこ とで4つ足アーチも出来るようになった。 写賣2-1 建案デザイナーに挑戦 (99.08.21)

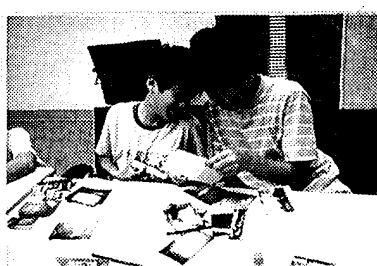

あらかじめ渡されていた使い捨てかメラ

で、自分の家やまちの第になる第所を撮

影した。写真をシートに整理し、コメン

トを入れることにより、単なる写夏が生 きた摆影データとして穊積される。

写真2-2 ガリバーマップでまち自慢（99.09.23）

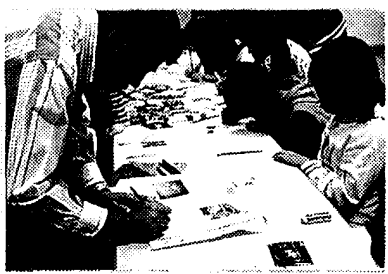

グルーブ毎に、使い唅てカメラでまちの 歷史や公共性のあるものを見つけて写真 撮影した。写賚をシートに貼り整理して いる。シートとして部録が残るため写真 撮影が樌標的な動機付けとなった。 写賣2-3 まちなみ探偵団(99.10.23)

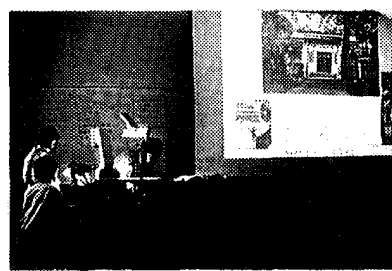

鼣榅結果をグループでまとめ発表する。 綢べてきたことを皆の前で発表すること も楽しみの一つとなった。地域に詳しい 人が少し解説を加えてくれることで、よ 理解が深まると考えられる。

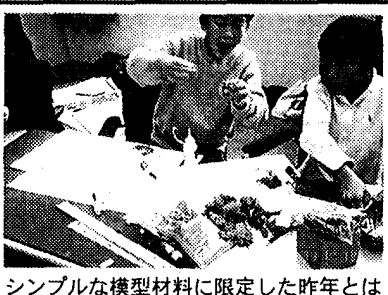

翼なり、豊䈪な材料を取りそろえた。日 頃見かけたことのない㷬型材料に子ども

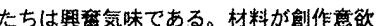
をかきたてることがわかる。

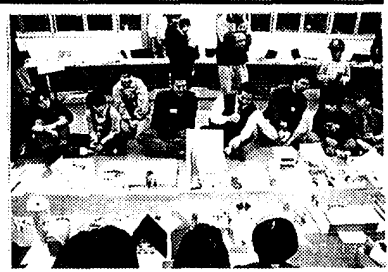
に見立ててみる。設計主旨を発表しなか ら、デザインの個性と街並みの調和にと の関係を話題にした。制作後に十分な話 し合いの時間をとることが重要である。 写真2-4 私の住んでみたい家(99.11.13)

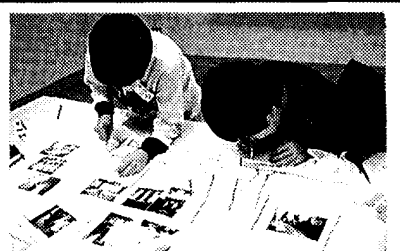

前半で蕃馈できた学区の写真を兴材とし て、自分たちの住むまちの紹介マップを 制作した。良く知っているまちでも新た な面白さに筑がつく。できれば参加者以 外に対する発表の場を設けたい。

写賣2-5 まちづくりゲーム $(99.12 .11)$

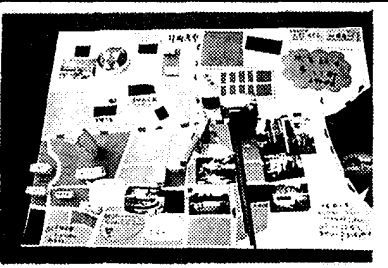

ユニークなまちの慗内マップが8枚完成 した。マップのテーマはは各々個性的で、 メンバーが变われば、紹介の視点が変わ ることを知った。まちの㭧力が、人に よって翼なることが理解できる。 
所は少なく，よく遊ぶ気に入りの場所 ${ }^{\mathrm{xv}}$ や近寄りたくない場所 $\mathrm{xv}$ が多い。発表時には地域各所にまつわるエピソードが，長年この地 に住み，WSに親子で参加しているP P A 会長から披露された。

子どもたちは，この写真撮影法による一連の作業に大変興味を示 している。中には他人か撮ったものを見ることで，自分の視点とは 異なることを発表時にコメントする子どももいた。親の中には，写 真を撮るために子どもたちと学区を散策する機会を得たことや，思 わぬもの（例：浄水場で昔使われていた仕切り弁）を発見した喜び を語っている。またある父親は，写真撮影が「自ら問題意識をもっ て参画していることにつながっている」と理解し, まちを注意深く 観察することの充実感を感想として述べている。（写真2-2）

\section{(3) [99 年第 3 回] 地域学習プログラム(2)}

\section{「まちなみ㗎偵団」：写真撮影法による環境資源発見}

\section{[小学生 14, 中学生 5, 親 8, 協カスタッフ 19 : 計 46 名]}

親子を基本単位とした 8 チームが使い捨てカメラを持って自由に 学区を探索し，様々な環境資源の収集を行った。前年の「好きな場 所，嫌いな場所」というテーマからやや踏み込んで，「将来にわた って大切にしたいもの」という観点で, 歴史性や公共性のあるもの を探すように指示した。これらは第 2 回のWSであまり撮影されな かったものであり，注目を促す意味もあった。時間の制限もあり学 区内を網羅的に探索することはできなかったが，中には目的を定め てかなり遠方まで出かけ，様々な要素湆収集したチームもあった。

帰ってきた後に，この地域の 100 年間の変化を地図を見せなが ら話した。これはまちで発見, 収集してきたものの, いわは謎解き となり，好評であった。発見したものが地域のどんな物理的, 文化 的, 時間的文脈と結びついているのかを理解することが，一連の作 業のつながりを理解するという意味だけでなく, 地域への理解や愛 着を深めていくきっかけとして重要と思われた。（写真2-3）

(4) [99 年第4 回] まちづくり学習プログラム(1)

\section{「私の住んでみたい家」：多彩な材料を使い, 条件を加味し} た模型制作

[小学生 13, 中学生 6, 親 7, 協力スタッフ $11:$ 計 37 名]

1 年目は材料を限定したが，2年目はできるだけ種類豊富に材料 をそろえた。昨年同様，敷地はA 3 版ボード内としたが，住宅のみ に専心した昨年の反省から制作上のルールとして，敷地内に自然的 要素を取り入れること, 外壁に木質の材料を使うこと, スケール感 の把握には人のミニチュアを作り，それを基本に考えることを指示 した。また, 施主と建築家の関係の一端を体験してもらうために, 住宅に盛り込む要素を親子でお互いに1つ注文することにした。

前年同様，ユニークな住宅模型が出揃った。最後に全模型を 2 列 に向かい合って並べ，通りを挟んだ住宅街のようにして各々作品を 紹介した。隣との外部空間や素材, 緑の連続性や調和の点から自慢 話や反省が聞かれ，模型でも条件設定によっては，まちづくりに関 するある一定の学習ができることをうかがわせた。（写真2-4）

(5) [99 年第 5 回] まちづくり学習プログラム(2)

「まちづくりゲーム」：地域マップづくり

[小学生 13, 中学生 4, 親 6, 協カスタッフ 9 : 計 32 名]

2 年目最後の WS では，それまでの WS で得られた写真等の材 料を基にして, 自分達の学区を紹介するための立体地域マップづく りを行った。グループ別に学区を紹介するためのキャッチコピーを 設定しこれに従ってマップを制作した。この作業は子どもたちに
とっては手慣れた作業のようであり，「古いような新しいまち」 「水と緑の多いまち」「裹通りが拈もしろいまち」「ハンディキャ ップゾーンのまち」「ドームのあるまち」などといった個性的な視 点の紹介マップが複数でき上がることになった。発表会では, 参加 親子相互が視点の違いに驚きを感ずる結果となった（写真 2-5）。

\section{5. まとめと今後の課題}

2 年間の WS を通じて, いくつかの成果と課題が明らかになっ てきた。学習プログラムに関して現時点での総括をする。

\section{5-1. 学習方法について}

\section{（1）巨大地図：簡単かつ客観的に地域を把握できる手法}

巨大地図は地域を一望でき, 他人の考え方や行動生活圈を把握し やすいと同時に, 自分の行動範囲も客観視できる。何よりも室内で 簡単にフィールドワークが行える特長がある（98 年第 2 回W Sは 雨天であり，この特長が生かされた）。今回は場所の位置関係がわ かりやすいように，建物や場所の名称が入った住宅地図を使用した が，建物の形を含めた地域の物理的形状をより意識した作業とする には，都市計画図や航空写真を使用することも考えられる。

\section{（2）写真撮影法 : 地域情報を簡単に収集，公達できる手法}

写真撮影法は巨大地図とともに, 誰もか簡単に参加できる有効な 方法であり，自ら写真をとることで参加意識を高めることができる。 特に表現力の未熟な子どもにとっては, 絵やスケッチよりも具体的 な対象を簡単に収集，表現，伝達できる手段，媒体である。具体性 があるため, シートやカードとしての整理や地図上へのプロット， 別の機会での再使用など, 様々な活用方法が考えられる。

（3）模型制作：直接体験的興味之感覚的理解を促す手法 等身大の構造模型や住宅模型の制作, 街づくり, マップつくりは, レンガや竹のような本物の素材や, 普段手にすることがない専門家 の使う材料や道具を使ったダイナミックな作業を通じて, 直接体験 的興味と感覚的理解を促す。建築や都市といった視点から生活環境 をデザインする機会を提供する優れた教材である。本来このような 制作は専門的な知識を統合し, 確認する作業として位置づけられる が, 子どもが興味津々の様子や感想文から, 内容によっては都市や 建築への関心や学習の動機付けとしても有効であると思われる。

（4）他者の存在の理解, 他者とのコミュニケーション

WSを通じて，まちにはいろいろな人がいるとや，多様な考え 方があることを理解するためには, 巨大地図などによる視覚的理解 や専門的解説による知的理解とともに，（協力スタッフを含む）他 者との直接的な接触機会が必要と思われる。そのためには意思の疎 通を促すための導入プログラムが不可欠となる。このWSでは人間 ストラクチャーやインタビューゲームを行ったが, 楽しみながらス キンシップを図っていくことが重要である。また「あのお姉さんが いるから行く」という子どももおり, 協力スタッフの存在は円滑な 実施への貢献だけでなく，親子の参加意欲に影響を与えている。

\section{（5）子どもと親のグルーピング}

同様な意図から親子を別の作業グループにしたり, それぞれが模 型制作するようにした。「別々になって少々焦った」という親の感 想もあったが，全般的には親子それぞれの特徵が出た成果物が生ま れた。しかし協同作業が伴う場合，コミュニケーションがうまくと れるようになるのに時間がかかり，本格的作業になかなか取りかか れなかったグループもあった。2 年目の住宅模型制作で試行した建 
築家と施主の関係の疑似体験のような仕掛けや，各回の発表会の方 法の工夫なども必要であろう。

\section{5-2. 学習内容と運営について}

\section{（1）身近な話題を対象とするプログラムの開発}

対象が小学生であり，具体的で魅力的な身近な話題によって， 地域環境が日常的な興味の対象になり得ると考えられる。そのため には，企画者に地域に精通した人材が必要である。この 2 年間では， WSの企画メンバーにそのような資質を持つ者はいなかったが，親 子で参加していたP T A 会長のWSの中での解説的な発言が, 参加 親子の地域理解に対する大きな助けになっていた。

\section{（2）連続性と完結性を備えたプログラム}

このWSは，動機づけからはじまり地域探索，まちづくりという 筋道を重視した。しかしまちを探索して学習したことが，まちづく りにどのように生かされるのかは明確でなく，WSの内容の相互関 連の追及がさらに必要である。その一方で，各回の完結性も重要で ある。模型制作はその達成感が明確なところに良さがある。さらに 成果発表や作業結果を紐解く専門的説明は，発見をきっかけに地域 理解を深め，さらなる関心を呼び起こすために不可欠な手順である。

\section{（3）専門性をわかりやすく伝える}

そのために手ほどきする側は，体験的学習の内容が専門性とどの ように結び付いているかを，専門的理論を弄することなくわかりや すく伝える方法を開発する必要がある。筆者らも 1 年目は技量の未 熟さのため相当苦労したが，この経験は広く共有されるべきと考え て，2年目からは進行や説明の役目を社会人の協力スタッフにも担 当してもらった。このような資質をもつ人材を地域に育てていくこ とは，継続性や地域的展開を考えると重要な課題である。

\section{（4）継続することの重要性}

当初は 1 年限りのつもりで始めたW S であるが, 親子や協力ス夕 ッフの要望から 2 年目を開催し， 3 年目も継続中である。 2 年連続 の参加，兄弟を連れてくる子や家族ぐるみでの参加，卒業後も友達 を誘って参加する中学生など, 参加者層は広がりつつある。毎回の WS を楽しみにする声とともに，内容の関連性に気づく親子も出て きており, 継続する重要性が回を重ねるごとに認識されつつある。

\section{（5）運営主体の問題あるいは地域とのつながり}

この試みはまちづくり学習の母体が全くない小学校区で, 数名の 専門家が小学生に対してプログラムを持ち込み参加を募るという， 利害関係のないWS としてスタートした。今後この試みが継続す るためには，地域との新たなつながりを模索しながら，地域と一緒 に運営主体を構成する必要があろう。そして, 参加者層の幅を広げ ることができれば，より多くの環境資源発掘が可能と思われる。

この他に実施資金の確保，親子の主体的取り組みへの工夫，協力 スタッフの役割，リーダーの資質など，このような学習型ワークシ ヨップの運営技術，方法に関する課題も浮かび上がってきている。 これについては次稿で報告したい。

謝辞：WSの開催に際して，98 年は建築学会東海支部から補助を得た。ま た 99 年の第 4 回目WS は建築学会東海支部設計計画委員会が企画実施した

「親と子の建築講座」との合同開催であった。さらにこの考察のとりまとめ には, (財) 東海学術奨励会の平成 11 年度助成を受けた。末筆であるが, 謝意を表したい。
(注)

例えば，集合住宅に関する延藤（千葉大）の一連の研究，まちづくりに関する佐藤 や卯月，後藤（いゔれも早稲田大）の研究など。

たとえば，参考文献 $1 ， 2 ， 3 ， 4$

iii 参考文献 5

iv 参考文献 6,7

このWSの企画は著者の他，金丸宜弘（曾根幸一環境設訪研究所），安井聡太郎 (藤川原設計），篠原佳則（安井建築事務所）の子ども建築研究会のメンバーが行 った。浅野聡助教授（三重大学）からは，事前に実践上の指導を受けた。WSの実 施にあたっては建部䜈治助教授（愛知工業大学），河合正吉氏(創建)の支援によ るところが大きい。

vi この小学校区は名古屋市の中心部近くに位置する。明治期には大半か㕪畑や荒れ地 であった。また戦時中は近くに軍需工場や陸軍工舟农存したが, 戦後はこれらの 大部分が法い下げられ，集合住宅や学校，公園などになった経緯がある。現在は， 幹線道路が走り，地域のほとんどが行街地化している。1998 年には，隣の学区に名 古屋ドームか完成した。なお，上野小学校は明治期から現在地にあり，100 年以上の 歴史を有する学校である。

vii 多くの親の参加を得たことは予想外であった。こうしたことに関心を寄せる層が潜 在的にあることを予想させるものである。

viii 参加者加は，98 年度には全回通じて一人 1000 円，99 年度には每回大人 1000 円， 子ども500 円の参加費を街収した。これは企画メンバー，(学生除く)協力スタッ フも同様である。

ix 人体を使って柱やアーチやヴォールトの力の流れを体で感じさせようとするもので ある。これはニューメキシコ大学のアン・テーラー女史か提案している「建築と子 どもかりキュラム」からヒントを得てアレンジを施した。

xこの回は，1996 年度建筑学会東海支部の建築設計計画委員会で筆者らが中心となっ て企画開催した「親と子の建築教空 : 木の和小屋・煉瓦のアーチ・ベニヤのドー ム」の経験を生かしたものである。このアイテアは中部大学工学部建築学科で学生 向けに行なっている実習をべースにしており，内藤和彦助教授の指導をいたたいた。

xi 参加親子から「レンガのアーチ」を成功させないとの声が上がり，1999 年3月に再 挑戦した。前回の失敗をふまえてまずアーチの理論を解説し，次にアーチに軸力の みがかかるよう，ロープをつかった懸垂曲線を合板に写取り，正確に型伜に反映さ せた。の時には 4 グループ全てがアーチを成功させることができた。

xii インタビューゲームでは，「好きな遊び」「好きな色」「学校の中で好きな場所」 「外国人に紹介したい場所」「家の中で好きな場听」を質問しあった。また認知地 図や学校の絵は，A 3の用紙に自由に表現させた。

xiii 結果として, 好きな場所として 102, や嫌いな場所として 98 , よく行く場所として 74 のシールか貼られた。好きな場所や嫌いな場所の地域的分布は，比較的粗密力゙見 られる結果となった。しかし，どの場所においても，好きな場所と嫌いな場所のシ 一ルは混在しており，またよく行く場所にもなっている場合が多い。よく行く，す なわちよく知っている場所は，生活者としての観点で様々なとらえ方がなされてい る。シールか密に貼られる場所は, 自宅周辺, 公園・緑道周辺, 上野小学校周辺, 公共施設周辺振甫プール・生涯学習センター，名古屋ドームなどであった。

xiv 材木屋（に执い），錦龍大神（私有地内のほこら），眼鏡橋，給水塔（歴史的建造 物)など。

xv 学区内に散在する公園や緑道か吓心であった。

xvi 暗い感じのする集合住宅や人気のない准宅地や店舗，通学路周辺の駐車場や工事現 場などである。

xvii 公共性の高いものとして,いくつかの公園が上げられ，特に公園内の自然に興味を 引かれていた。街路の景観や表出, ハンディキャップゾーンの様々な仕掛けなど, 歩道を中心とした様々な環境要素を拾うチームもあった。しかし小学校だけでなく コミュニティセンター, 病院など公共施設か散在している地域であるものの，これ らを撮影したものは少なく，地域施設としての存在感の希薄さを浮き彫りにした。 歷史性のあるものとしては, いくつかの神社や持寺が挙げられた。戦争時代にあっ た軍需工場の垪や，普段は気付かないような記念碑をみつけたたチームもあった。

\section{(参考文献およひ既発表論文)}

1) ヘンリー・サノフ『まちづくりゲーム」晶文社, 1993

2) こどもとまちづくり研究会「こどもとまちづくり」風土社, 1996

3）住宅総合研究財団「まちはこどものワンダーランド風土社, 1998

4）浦安まちブックをつくる会「まちづくりがわかる本」彰国社，1999

5）稲葉武司：インスタントカメラを利用した町並みウォッチング，建築学会技術報告 集第 1号, pp317-320, 1995.12

6）倉原宗孝: 子どもたちの体験活動による住民参加のまちつ゚くり促進に関する研究， 建築学会計画系論文集第 483 号, pp. 179-188, 1996.5

7）會原宗孝:市民的まちづくり学習としての住民渗加のワクショップに関する考察， 建筑学会計画系論文集第 520 号, pp. 255-262, 1999.6

8）鈴木堅一，小松 尚、中井孝幸：学習型環境デザインワークショップの実践と課題 親子の地域学習プログラムの開発に関する報告 その1, 日本建築学会東海支部研 究報告第3 8号, pp. 813-816, 2000.2

9）小松 尚，鈴木賢一，中井孝幸：巨大地図及び写真投影法による地域環境資源の発 掘 親子の地域学習プログラムの開発に関する報告 その 2 , 日本建築学会東海支 部研究報告第3 8号, pp. 817-820,2000.2

10）鈴木賢一他：親子の地域学習プログラムの開発に関する報告，(財) 住宅棇合研究 財団住教育委員会編集「住まい・まち学習」論文発表会資料，pp. 37-42，2000.3

[2000年 4 月19日原稿受理 2000 年 7 月26日採用決定］ 